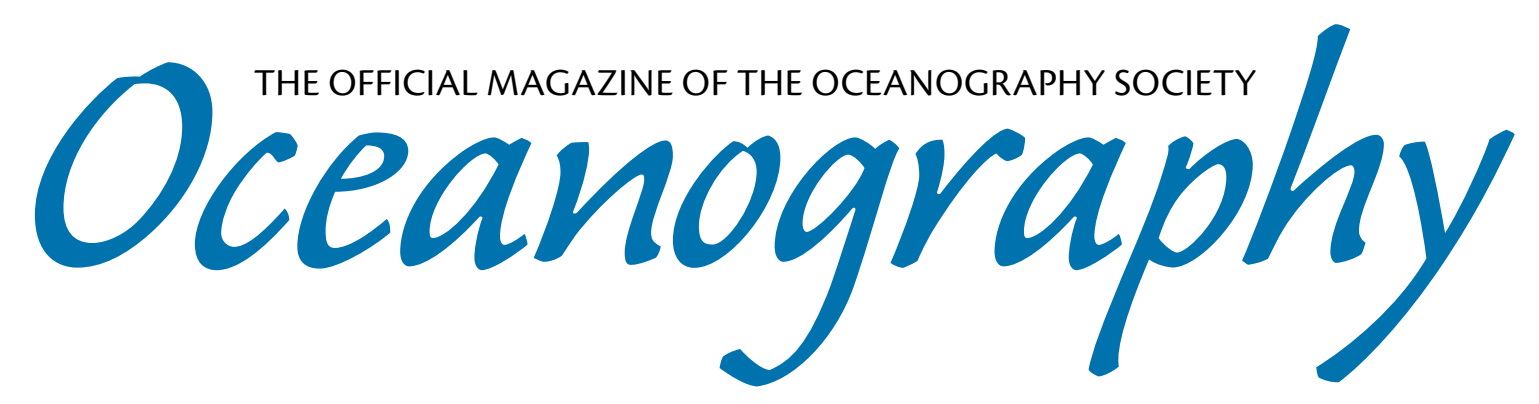

CITATION

Lee, D.-K., and L. Centurioni. 2013. The Wintertime Subtropical Current in the northwestern

Pacific. Oceanography 26(1):28-37, http://dx.doi.org/10.5670/oceanog.2013.02.

DOI

http://dx.doi.org/10.5670/oceanog.2013.02

COPYRIGHT

This article has been published in Oceanography, Volume 26, Number 1, a quarterly journal of The Oceanography Society. Copyright 2013 by The Oceanography Society. All rights reserved.

USAGE

Permission is granted to copy this article for use in teaching and research. Republication, systematic reproduction, or collective redistribution of any portion of this article by photocopy machine, reposting, or other means is permitted only with the approval of The Oceanography Society. Send all correspondence to: info@tos.org or The Oceanography Society, PO Box 1931, Rockville, MD 20849-1931, USA. 


\section{THE \\ WINTERTIME SUBTROPICAL CURRENT IN THE NORTHWESTERN PACIFIC}

BY DONG-KYU LEE

AND LUCA CENTURIONI

Testing a holey sock type drifter with current meter and dye.

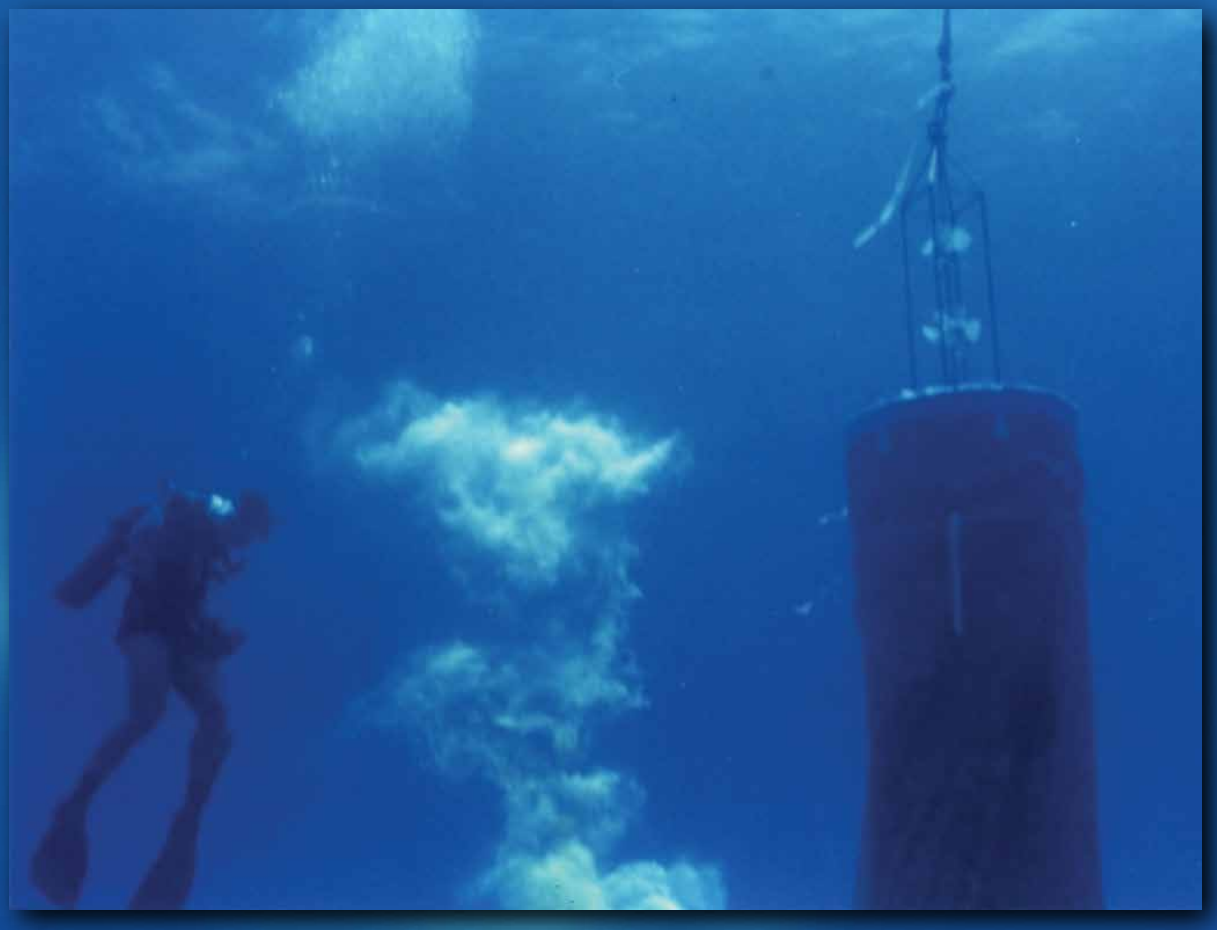

ABSTRACT. The strong wintertime westward current in the northwestern Pacific between $18^{\circ} \mathrm{N}$ and $23^{\circ} \mathrm{N}$ was investigated using data from satellite-tracked drifters. The decadal strengthening of the negative wind stress curl and trade wind in the subtropical area north of Hawaii and west of $150^{\circ} \mathrm{E}$ drives the decadal variability of this wintertime current. The Sverdrup transport computed from a high-resolution $\left(1^{\circ} \times 1^{\circ}\right)$ wind stress reanalysis product reproduces the Wintertime Subtropical Current (WSTC) well, and shows that its Sverdrup transport increases in excess of $15 \mathrm{~Sv}\left(1 \mathrm{~Sv}=10^{6} \mathrm{~m}^{3} \mathrm{~s}^{-1}\right)$ from the early $1970 \mathrm{~s}$ to the $1990 \mathrm{~s}$. The annual variation of the WSTC transport is well correlated with the North Pacific Index, which represents the strength of the Aleutian Low before the 1988/89 climate shift, but the correlation with teleconnection patterns or climate indices becomes weak after the 1988/89 shift. The annual fluctuations of WSTC transport are found to be reflected in the springtime Kuroshio transport south of Japan. 


\section{INTRODUCTION AND}

\section{METHODS}

Recent absolute sea level estimated from drifter-measured geostrophic current data, satellite altimetry, and satellite measured gravity (Maximenko et al., 2009) reveals a rather complicated interior structure of the subtropical gyre in the western Pacific (Figure 1a), more complicated than can be explained using a Sverdrup wind-driven theory. Major geostrophic currents of the gyre (western boundary current and North Equatorial Current) remain properly located as wind-driven circulation theory states, but eastward subtropical countercurrents, especially the northern subtropical front (Kobashi et al., 2006), give the southern part of the gyre a forked fishtail shape. This study focuses on the seasonal and interdecadal changes in the circulation of the southern part of the subtropical gyre in a region centered along the southern subtropical front (Figure 1a).

Monsoonal wind shifts contribute significantly to the seasonal modulation of the currents of the western subtropical Pacific (Rudnick et al., 2011). The most prominent seasonal feature of the surface circulation is the Kuroshio entering the South China Sea (SCS) through Luzon Strait from October through March, when strong monsoon winds blow from the northeast (Centurioni et al., 2004, 2009). A second noticeable winter circulation pattern of the subtropical North Pacific is a well-organized westward zonal current centered along $20^{\circ} \mathrm{N}$ in the Luzon Strait area, with average westward speeds ranging from $0.20-0.35 \mathrm{~m} \mathrm{~s}^{-1}$ (Centurioni et al., 2004).

Ishi and Hanawa (2005) noted that the Sverdrup transport at the western boundary between $25^{\circ} \mathrm{N}$ and $30^{\circ} \mathrm{N}$ is

strongly correlated with wintertime wind stress curl over the North Pacific Ocean $\left(20^{\circ}-60^{\circ} \mathrm{N}, 120^{\circ}-110^{\circ} \mathrm{W}\right)$. The Kuroshio transport south of Japan also exhibits seasonal variations, with minimum values occurring in March and maximum values occurring in September (Kakinoki et al., 2008).

On interdecadal time scales, the wind stress curl over the North Pacific Ocean shows notable changes, especially in

\section{S $S_{\text {WE FOUND THE ANNUAL FLUCTUATIONS OF }}$ [WINTERTIME SUBTROPICAL CURRENT] TRANSPORT ARE REFLECTED IN THE SPRINGTIME KUROSHIO TRANSPORT SOUTH OF JAPAN.}

winter (Ishi and Hanawa, 2005), that result in an intensification of the western part of the North Pacific subtropical gyre (Yasuda and Hanawa, 1997; Miller et al. 1998; Deser et al., 1999). The changes in ocean current regimes result from an increased southward Ekman transport of cold water from the north due to intensified Westerlies that cool the North Pacific Subtropical Mode Water (NPSTMW; Yasuda and Hanawa, 1997).

This paper describes a wintertime feature of Northwest Pacific circulation, namely the westward zonal current centered along $20^{\circ} \mathrm{N}$ and stretching from the dateline to the Luzon Strait region, whose westward limb was first observed by Centurioni et al. (2004). We term this current the Wintertime Subtropical Current (WSTC; Figure 1b). The mean geostrophic current north of $15^{\circ} \mathrm{N}$ is mostly eastward with a magnitude of 2-6 $\mathrm{cm} \mathrm{s}^{-1}$ (see Figure $5 \mathrm{c}$ of Maximenko et al., 2009), and the WSTC (Figure 1b) is located in the zonal band between two eastward Subtropical Counter Currents (STCCs; Kobashi et al., 2006) that are well defined in summer (Figure 1c).

Unless noted otherwise, throughout the paper we refer to winter as the period between October and March, and to summer as the period between April and September. The monthly wind stress data used to compute the Sverdrup transport are from the European Center of Medium-Range Weather Forecasts (ECMWF) Ocean Analysis System ORA-S3 (Balmaseda et al., 2008). This reanalysis product has a higher horizontal spatial resolution $\left(1^{\circ} \times 1^{\circ}\right)$ than most commonly available reanalysis products, such as one available from the National Centers for Environmental Prediction (NCEP; $2.5^{\circ} \times 2.5^{\circ}$ ), and it spans the period from 1959 through 2009 . The $15 \mathrm{~m}$ deep ocean velocity data are from the Global Drifter Program (GDP) archive (Niiler, 2001) and span the period from 1992 through 2011. We use

Dong-Kyu Lee (dglee@pusan.ac.kr) is Professor, Pusan National University, Department of Oceanography, Busan, Korea. Luca Centurioni is Associate Researcher, Scripps Institution of Oceanography, University of California, San Diego, La Jolla, CA, USA. 
NCEP reanalysis winds to compute the unbiased geostrophic velocity at $15 \mathrm{~m}$ depth. To compute an unbiased seasonal mean current, the total (geostrophic plus ageostrophic) $15 \mathrm{~m}$ depth velocity $(V)$ is decomposed into an unknown, unbiased mean geostrophic current $\left(V_{g m}\right)$, a geostrophic velocity anomaly that can be estimated, for example, from satellite sea level anomaly data $\left(V_{g}^{\prime}\right)$ and an Ekman current. See Centurioni et al. (2009) for a full description of the methodology to estimate the unbiased mean geostrophic current. The geostrophic velocity anomaly, $V_{g}^{\prime}$, is computed from the merged sea level anomaly delayed quality controlled data from Archiving, Validation and Interpretation of Satellite Oceanographic Data (AVISO; ftp.aviso.oceanobs.com) available from 1993 and ongoing. After estimating regression parameters from all available data sets, we computed the total seasonal (winter and summer) $15 \mathrm{~m}$ depth velocities using seasonal means of $V_{g}^{\prime}$ and wind in $2^{\circ}$ (longitude) by $1^{\circ}$ (latitude) spatial bins.

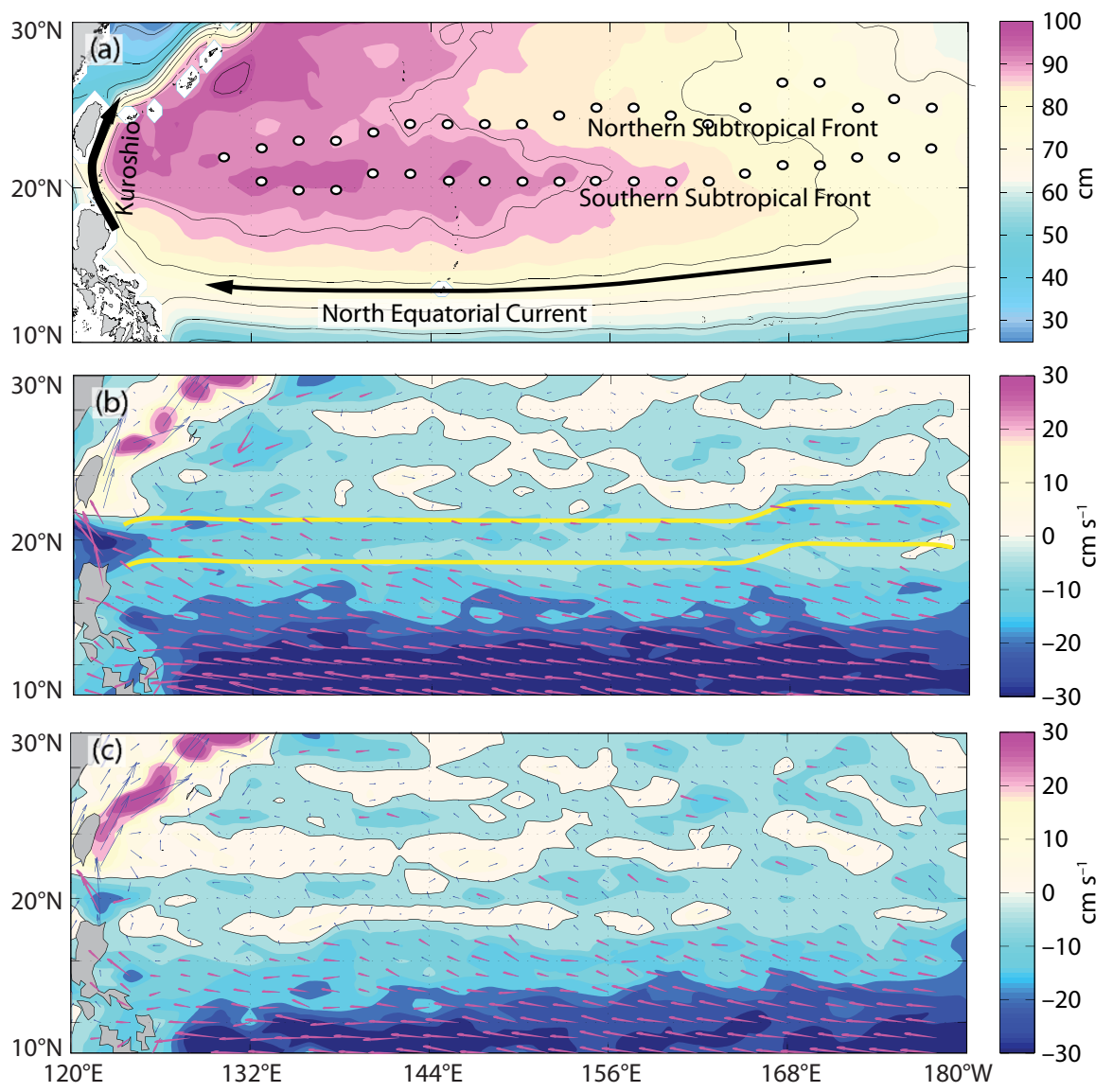

Figure 1. (a) Absolute mean sea level from historical Global Drifter Program drifters and satellite measured gravity data from Maximenko et al. (2009). The locations of major currents and subtropical fronts (open circles) detected by Kobashi et al. (2006) are also plotted. (b) Current vectors (red arrows for westward zonal current larger than $7 \mathrm{~cm} \mathrm{~s}^{-1}$ ) from combined mean geostrophic and Ekman velocities for winter (October to March) and (c) summer (April to September). Two thick yellow lines denote the zonal band where the Wintertime Subtropical Current is located. The zonal current speed is represented by color shading, and black contour lines denote the zero zonal current. The plots were obtained by combining drifter, satellite, and NCEP wind data for the period 1992-2011, as explained in the text.
The annual variation of the WSTC volume transport is computed from the Sverdrup balance, and the dramatic increase in winter wind-driven transport in the subtropical area from the 1970s to the 1990s is discussed in the next section. The section after that discusses the variability of the WSTC on interdecadal time scales and its correlation with several climate indices. Summary and discussion are given in the final section of this paper.

\section{WINTERTIME SUBTROPICAL \\ CURRENT}

\section{Observations of the Seasonal}

Currents in the Northwestern Subtropical Pacific

The $15 \mathrm{~m}$ depth ocean currents of the northwestern subtropical Pacific computed by combining drifter, satellite altimetry velocity data, and reanalysis winds show large seasonal variations (Figure 1b,c), as expected given the seasonally varying forcing of the monsoon wind (Rudnick et al., 2011). We focus on the well-defined wintertime westward zonal current that occurs in the western subtropical Pacific band centered at $\sim 20^{\circ} \mathrm{N}$ (Figure $1 \mathrm{~b}$ ). This approximately $400 \mathrm{~km}$ wide current stretches from the dateline to the western boundary current. In summer, the zonal westward current near the western boundary is much weaker, although still present (Figure 1c). The WSTC (Figure 1b) appears as a northward extension of the wintertime North Equatorial Current (NEC), but we show later that the NEC and the WSTC are two distinctly separate currents. The WSTC Sverdrup transport anomalies also exhibit decadal changes that are well correlated with the atmospheric teleconnection patterns and the Kuroshio transport. 


\section{Decadal Changes in WSTC}

\section{Sverdrup Transport}

The vertically integrated meridional transport from the steady-state Sverdrup relation can be written as (e.g., Gill, 1982)

$V=\frac{1}{\beta \rho_{0}}\left(\frac{\partial \tau_{y}}{\partial x}+\frac{\partial \tau_{x}}{\partial y}\right)$

and the two-dimensional stream function $\varphi$ can be defined as

$V=-\frac{\partial \varphi}{\partial x}, U=\frac{\partial \varphi}{\partial y}$.

The steady-state Sverdrup transport stream function at longitude $x$ and latitude $y$ then becomes

$$
\begin{gathered}
\varphi(x, y)= \\
\frac{-1}{\beta \rho_{0}} \int_{x_{E}}^{x}\left(\frac{\partial \tau_{y}\left(x^{\prime}, y\right)}{\partial x}+\frac{\partial \tau_{x}\left(x^{\prime}, y\right)}{\partial y}\right) \partial x^{\prime}
\end{gathered}
$$

Here, $\beta$ is the latitudinal gradient of the Coriolis parameter; $U$ and $V$ are the vertically integrated zonal and meridional transports, respectively; $\rho_{0}$ is the density of seawater; $x_{E}$ is the coordinate of the eastern boundary; and $\left(\tau_{x}, \tau_{y}\right)$ is the zonal and meridional component of the wind stress.

The Sverdrup transport stream function is computed by integrating Equation 2 westward from the eastern boundary. The mean wintertime transport, averaged for the 1993-2002 period (Figure 2a), shows a much stronger westward flow in the subtropical gyre when compared to the mean Sverdrup transport presented by Ishi and Hanawa (2005), and it has more small-scale features that result from the higher spatial resolution of the ECMWF wind field used in this analysis. We chose the decades 1993-2002 and 1964-1973 to illustrate the decadal changes of the WSTC Sverdrup transport because these changes exhibit (Figure 3) absolute maximum and minimum values, respectively, when averaged over these time intervals. Because the Hawaiian Islands (not shown) do not significantly affect the Sverdrup transport stream function in the western boundary region, the localized, small-scale strong wind stress curl in the lee of the Hawaiian mountains (Figure 4) are removed for the Sverdrup stream function calculation shown in Figure 2.

Ishi and Hanawa (2005) found a near-unity correlation between the time series of the first mode of the Empirical Orthogonal Function (EOF) of the climatological winter wind stress curl field and the Sverdrup transport at $25^{\circ}-30^{\circ} \mathrm{N}$.
The decadal variation of the wintertime Sverdrup stream function between the years 1964-1973 and 1993-2002 at the subtropical western boundary is approximately $10 \mathrm{~Sv}$ in Figure 3, and the intensification occurs in the latitude band between $18^{\circ} \mathrm{N}$ and $22^{\circ} \mathrm{N}$ (Figure 2b), that is, where the WSTC is observed (see Figure 1a). The mean summer Sverdrup stream function averaged between 1993 and 2002 (Figure 2c) is approximately half of the winter value and has a weaker meridional gradient in the southern part of the subtropical gyre. The decadal changes in summer Sverdrup transport between $15^{\circ} \mathrm{N}$ and $23^{\circ} \mathrm{N}$ are similar (about $10 \mathrm{~Sv}$ ) to those in winter transport, but the direction
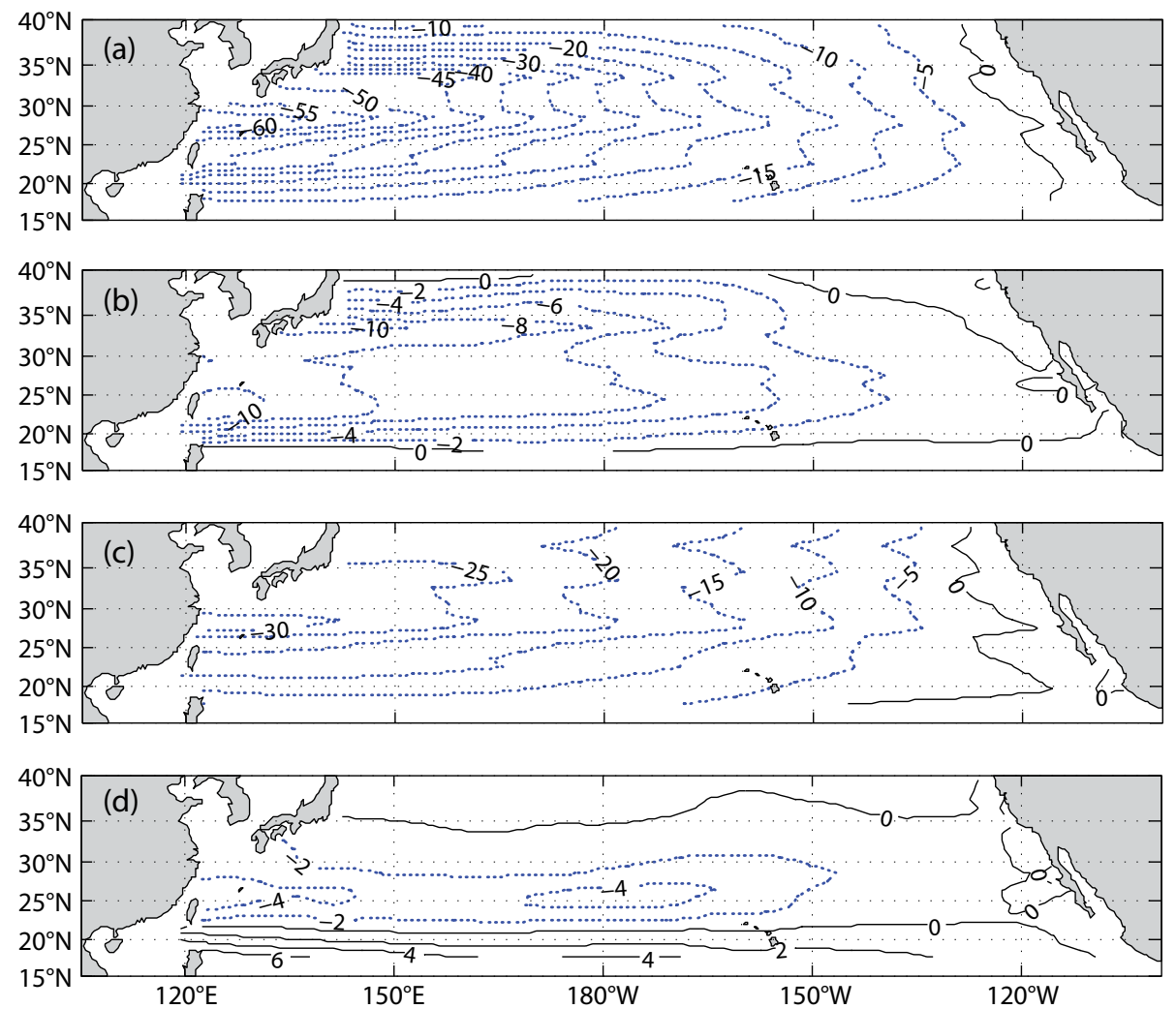

Figure 2. (a) Mean winter (October to March) Sverdrup transport stream function during the 1993-2002 period, and (b) change in the Sverdrup transport stream function (1993-2002 winter period minus 1964-1973 winter period). (c) Mean summer (April to September) Sverdrup transport stream function during the 1993-2002 period, and (d) change in Sverdrup transport stream function (1993-2002 summer period minus 1964-1973 summer period). 
of the Sverdrup transport changes from westward in the 1964-1973 period to eastward in the 1993-2002 period (Figure 2d). Apparently, the summer southern STCC (Kobashi et al., 2006) is strengthened from the 1964-1973 period to the 1993-2002 period.

The zonal transport at the western

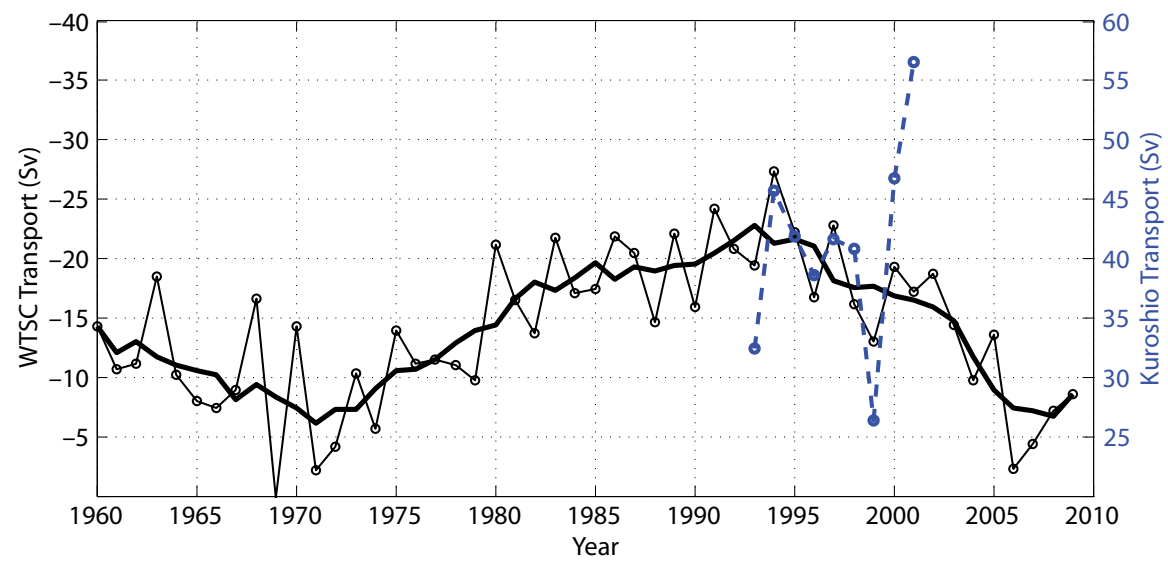

Figure 3. Mean Sverdrup transport at $122.5^{\circ} \mathrm{E}$ in winter (October to March) between $18.5^{\circ} \mathrm{N}$ and $22.5^{\circ} \mathrm{N}$ (black lines, left y axis) and Kuroshio transport (dashed line, right y axis). The thick black line is the five-year running mean transport obtained from the time series marked by the thin black line.
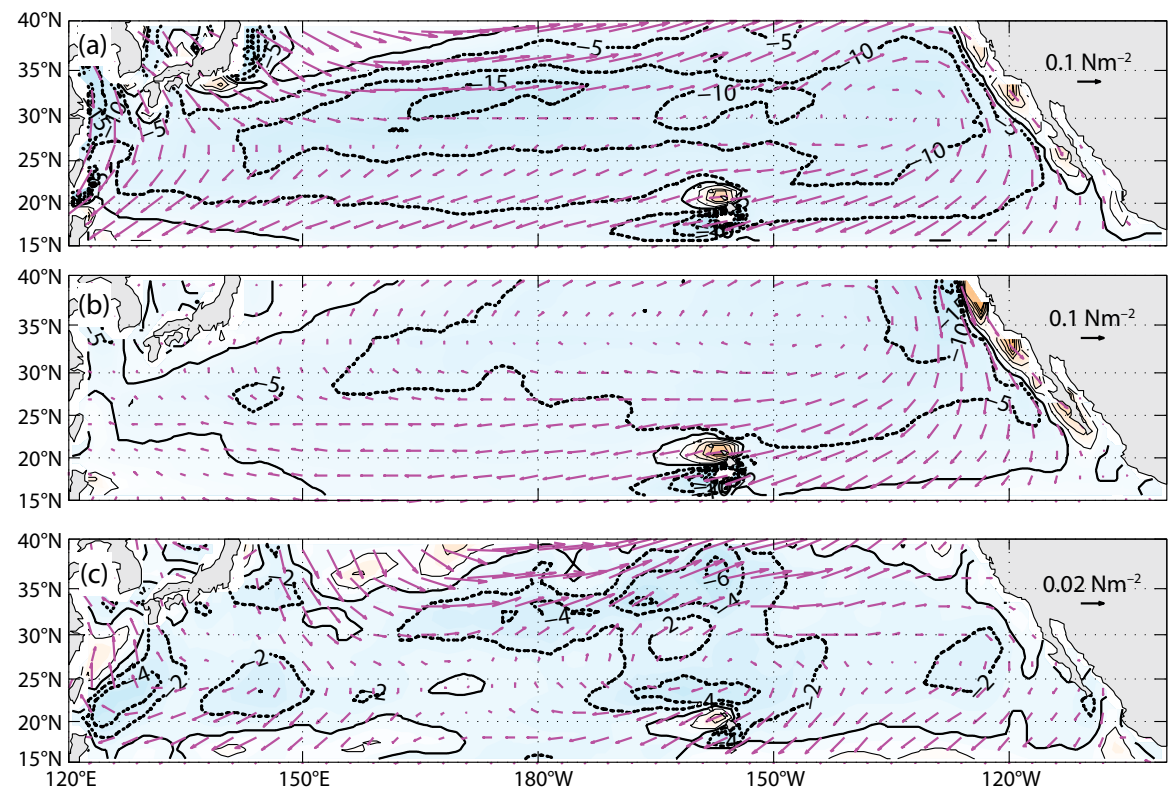

Figure 4. Wind stress (vectors) and wind stress curl (contour interval of $5 \times 10^{-8} \mathrm{~N} \mathrm{~m}^{-3}$ ) in (a) winter during the 1993-2002 period and (b) summer during the 1993-2002 period. (c) Decadal change in winter wind stress and wind stress curl (1993-2002 period minus 1964-1973 period). all-time maximum value of $23 \mathrm{SV}$ in 1996, and in just 10 years, from 1996 to 2006, it drops back to the minimum value observed in 1970. An accelerated decreasing trend occurs from 2002 through 2006.

Several observations corroborate the hypothesis that part of the WSTC feeds into the wintertime Kuroshio as it meanders from the Philippine Sea into the South China Sea through Luzon Strait. Yearly fluctuations of the WSTC transport, as defined above, are positively correlated with changes in volume transport of the Kuroshio estimated from an inverted echosounder (IES) array and TOPEX/Poseidon altimeter data along the Affiliated Surveys of the Kuroshio off Cape Ashizuri (ASUKA) line in 19932001 (Kakinoki et al., 2008; Figure 3). The correlation coefficient is 0.89 after excluding the winter of 2001. In 2000/01, unlike other years, the southernmost IES mooring station was positioned north of the southern boundary of the Kuroshio because of where the current meandered (Kawabe, 2005), and it probably caused the large uncertainty in 2001 Kuroshio transport. The correlation between Kuroshio volume transport and WSTC transport is highly sensitive to the averaging interval of the Kuroshio transport because there is a time lag of the order of four to seven months between the two time series. We found that the largest correlation between the two time series is achieved when using a three-month averaging window. Figure 3 shows the Kuroshio transport (dashed line) averaged from May to July for 1993-2001. To our knowledge, the geostrophic transport computation by Kakinoki et al. (2008) is the only published transport time series with sampling intervals 
shorter than one month. If the Sverdrup transport signal is advected by the WSTC and then by the Kuroshio, the positive correlation between the series of WSTC and Kuroshio transports implies an ocean response time to wind stress curl forcing of 2.5-5.5 months. Employing an average Kuroshio transport speed of $0.3 \mathrm{~m} \mathrm{~s}^{-1}$, based on an estimate of $21 \mathrm{~Sv}$ over a $7 \times 10^{7} \mathrm{~m}^{2}$ area in the East Taiwan Channel (Johns et al., 2001), indicates that the water mass requires approximately 45 days to cover the $1,200 \mathrm{~km}$ from the region where WSTC Sverdrup transport is computed to the ASUKA line.

\section{Wind Forcing of the WSTC}

Deser et al. (1999) show that the westward intensification of the North Pacific subtropical gyre is related to temporal changes of the wind stress curl field. Decadal changes in the wind stress therefore must play a central role in modulating the intensification of the subtropical gyre on interdecadal scales (Yasuda and Hanawa, 1997). We chose the decade when the WSTC Sverdrup transport is maximum (1993-2002; Figure 3) to illustrate that the most significant seasonal changes in wind stress and wind stress curl over the North Pacific occur in the regions of the western trade wind and the northern Westerlies (Figure 4a,b). There is a broad area of large negative wind stress curl over the whole domain, and its magnitude is larger in winter (Figure 4a) than in summer (Figure $4 \mathrm{~b}$ ) by approximately a factor of two.

The decadal variation in winter wind stress and wind stress curl (1993-2002 minus 1964-1973, i.e., the periods for which the WSTC Sverdrup transport is maximum and minimum, respectively; Figure 4c) is due to intensification of the negative wind stress curl throughout the basin, with the largest strengthening observed in the western subtropical region and in the northern Westerlies region. The decadal changes in the winter wind stress vector field presented here differ significantly from the annual mean values presented by Deser et al. (1999). The Sverdrup transport time series (Figure 3) suggests that the WSTC should nearly disappear during the winters of 2006-2009. It should then resume in 2010, when the WSTC Sverdrup transport, computed from satellite winds from the Advanced Scatterometer (ASCAT) satellite (Bentamy and Croize Fillon, 2012), is $17 \mathrm{~Sv}$.

Strengthening of the WSTC surface current signature is also observed as a well-defined band of westward geostrophic flow north of $18^{\circ} \mathrm{N}$ (Figure 5a) when computed by combining the AVISO sea surface height anomaly with the mean dynamic topography of Maximenko et al. (2009). The geostrophic signature of the WSTC is most apparent when the average is computed between January and March, probably as a result of the time needed for the geostrophic component associated with the Sverdrup transport to achieve a nearly steady state. In the 1994-1997 period, the WSTC Sverdrup transport reaches an all-time maximum. At the same time, observations show that the Subtropical Counter Current north of $17^{\circ} \mathrm{N}$ becomes weak and then disappears west of $160^{\circ} \mathrm{E}$. Conversely, the 2006-2009 winter average shows that the Subtropical Counter Current that stretches as far west as $126^{\circ} \mathrm{E}$ replaces the WSTC, with a small gap between $138^{\circ} \mathrm{E}$ and $141^{\circ} \mathrm{E}$ (Figure 5b). The averaging intervals (1994-1997 and 2006-2009) are different

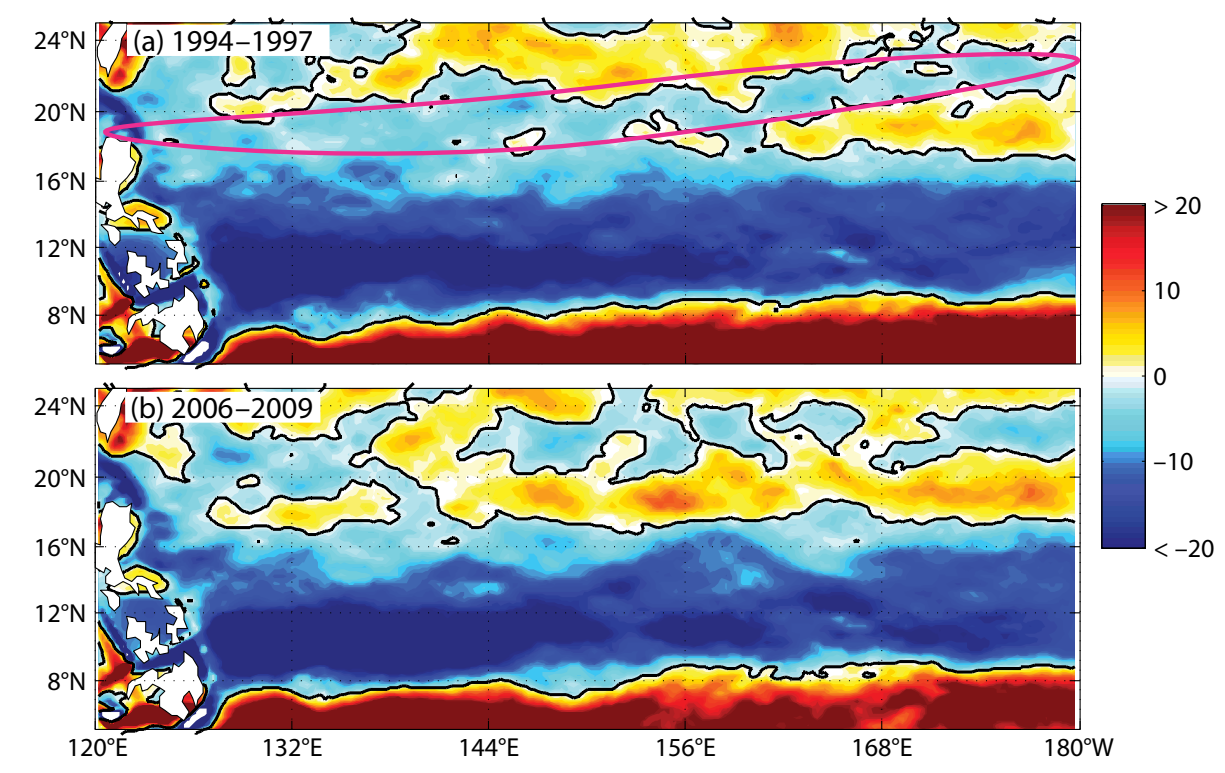

Figure 5. Mean zonal geostrophic current in the subtropical western Pacific (a) in the January to March period during 1994-1997 and (b) in the January to March period during 2006-2009. The Wintertime Subtropical Current is marked in red. The geostrophic current is estimated from the multimission merged sea level anomaly field after removing eddies using the method described in Lee and Niiler (2010) and adding the mean sea level from Maximenko et al. (2009). 
from those used for the Sverdrup transport comparison because the satellite altimetry time series starts in 1992.

The NEC boundary reaches its northernmost position in winter and is separated from the WSTC by a zonal geostrophic and Ekman velocity minimum at $\sim 17^{\circ} \mathrm{N}, 140^{\circ}-145^{\circ} \mathrm{E}$ for both strong (1994-1997) and weak (2006-2008) WSTC occurrences (Figure 6). The wintertime Ekman current at $15 \mathrm{~m}$ depth is estimated from NCEP winds using the method described earlier. Figure 6 indicates that the WSTC should not be considered as a northward wintertime extension of the NEC. The westward mean Ekman Current averaged over $140^{\circ}-145^{\circ} \mathrm{N}$ in the WSTC region is of greater magnitude than the westward geostrophic current when the Sverdrup transport of the WSTC is the largest (Figure 6b).

It is difficult to obtain observational evidence of the WSTC because of its strong decadal variability and large ageostrophic component. A high-resolution reanalysis from the ocean general circulation model HYbrid Coordinate Ocean Model (HYCOM; Chassignet et al., 2009) is therefore used here to provide further evidence of the existence of the WSTC. HYCOM data are available from November 1, 2003, and Figure 7a shows the winter mean $(2004 / 05)$ of
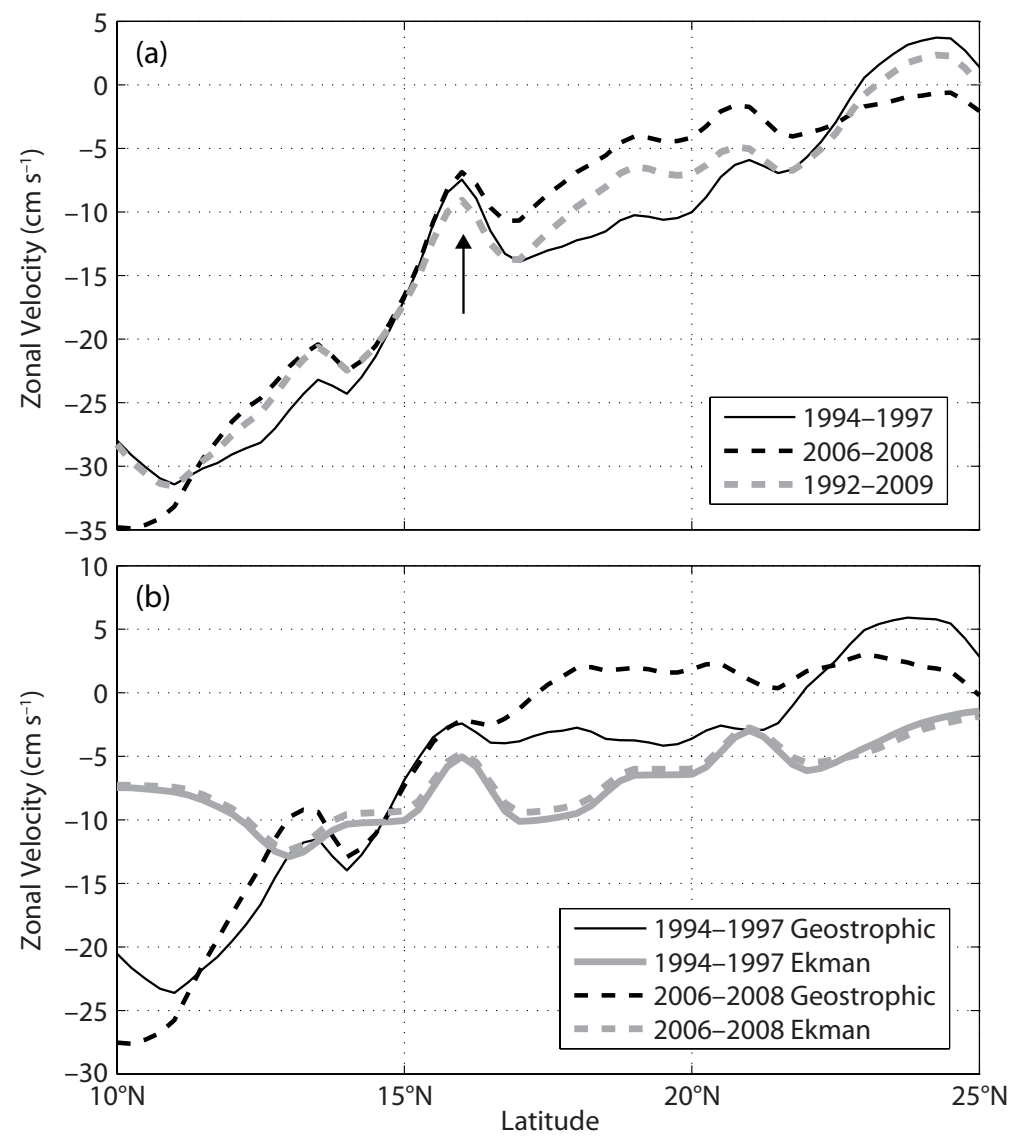

Figure 6. Meridional profiles of (a) winter (December to February) zonal total current, and (b) winter zonal geostrophic and Ekman current averaged between $140^{\circ} \mathrm{E}$ and $145^{\circ} \mathrm{E}$. The arrow marks the northern boundary of the North Equatorial Current.

zonal current at $15 \mathrm{~m}$. The years 2004 and 2005 are chosen because the WSTC Sverdrup transports (Figure 3) are larger than for other years in the available HYCOM data set. A strong zonal westward current (larger than $10 \mathrm{~cm}$ $\mathrm{s}^{-1}$ ) occurs in the latitude band between $19^{\circ} \mathrm{N}$ and $23^{\circ} \mathrm{N}$ and reaches deeper than the NEC (dotted box in Figure 7b). With the exception of 2007 (El Niño year), the variation and magnitude of the volume transport from HYCOM averaged between $150^{\circ} \mathrm{E}$ and $155^{\circ} \mathrm{E}$ (dotted box in Figure 7a) are well correlated with the WSTC Sverdrup transport time series in the same longitudinal band (Figure 7c). HYCOM successfully reproduces the WSTC Sverdrup transport for the 2010 El Niño. Explaining the large discrepancy in 2007 is beyond the scope of this paper, but it may come from the fact that HYCOM data before September 2008 are not from the current version but from the legacy version.

\section{THE WSTC SVERDRUP}

\section{TRANSPORT AND THE CLIMATE}

Ishi and Hanawa (2005) found a high negative correlation ( 0.93 ) between the first EOF mode of the winter wind stress curl and the North Pacific Index (Trenberth and Hurrel, 1994). They also report a near-unity correlation between the Sverdrup transport at $24^{\circ}-30^{\circ} \mathrm{N}$ and the first EOF mode of the wintertime wind stress curl. Similarly, in our analysis, the WSTC transport is positively (correlation coefficient of 0.74 ) and negatively (correlation coefficient of -0.75) correlated with the first EOF mode of the wintertime wind stress curl and North Pacific Index, respectfully, up to the 1988/89 climate transition (Figure 8a,b). The most notable climate transition of 
$1976 / 77$ is related to the Pacific Decadal Oscillation (Mantua et al., 1997). Yeh et al. (2011) show that the area mean winter sea surface temperature anomaly in the North Pacific becomes positive after 1988 and, consequently, the $1988 / 89$ climate transition is caused by different dynamics compared to the 1976/77 climate transition. The difference in the results between this study and Ishi and Hanawa (2005) is primarily due to the use of higher spatial resolution wind data and different averaging windows. It is interesting to note that the WSTC transport has a tendency to lead the North Pacific Index by one year during the 1990-2000 period and in 2009 (Figure 8b).

\section{SUMMARY AND DISCUSSION}

This paper provides observational evidence from drifter, altimetry, and wind data of the existence of the WSTC, which appears to be an independent current rather than the result of northward migration of the NEC in winter. The wind stress curl appears to be the main driving force for wintertime formation of the WSTC, which is also successfully reproduced by the Sverdrup transport computation presented here. Strengthening of the negative wind stress curl in the subtropical area north of Hawaii and west of $150^{\circ} \mathrm{E}$ intensifies the westward zonal current in the area south of the Subtropical Counter Current and north of the North Equatorial Current. Decadal variations of the WSTC are greater than changes in eastward Kuroshio transport south of Japan. Ocean models, forced with observed winds (see, for example Miller et al., 1998) demonstrate similar features, but they fail to explain the large decadal
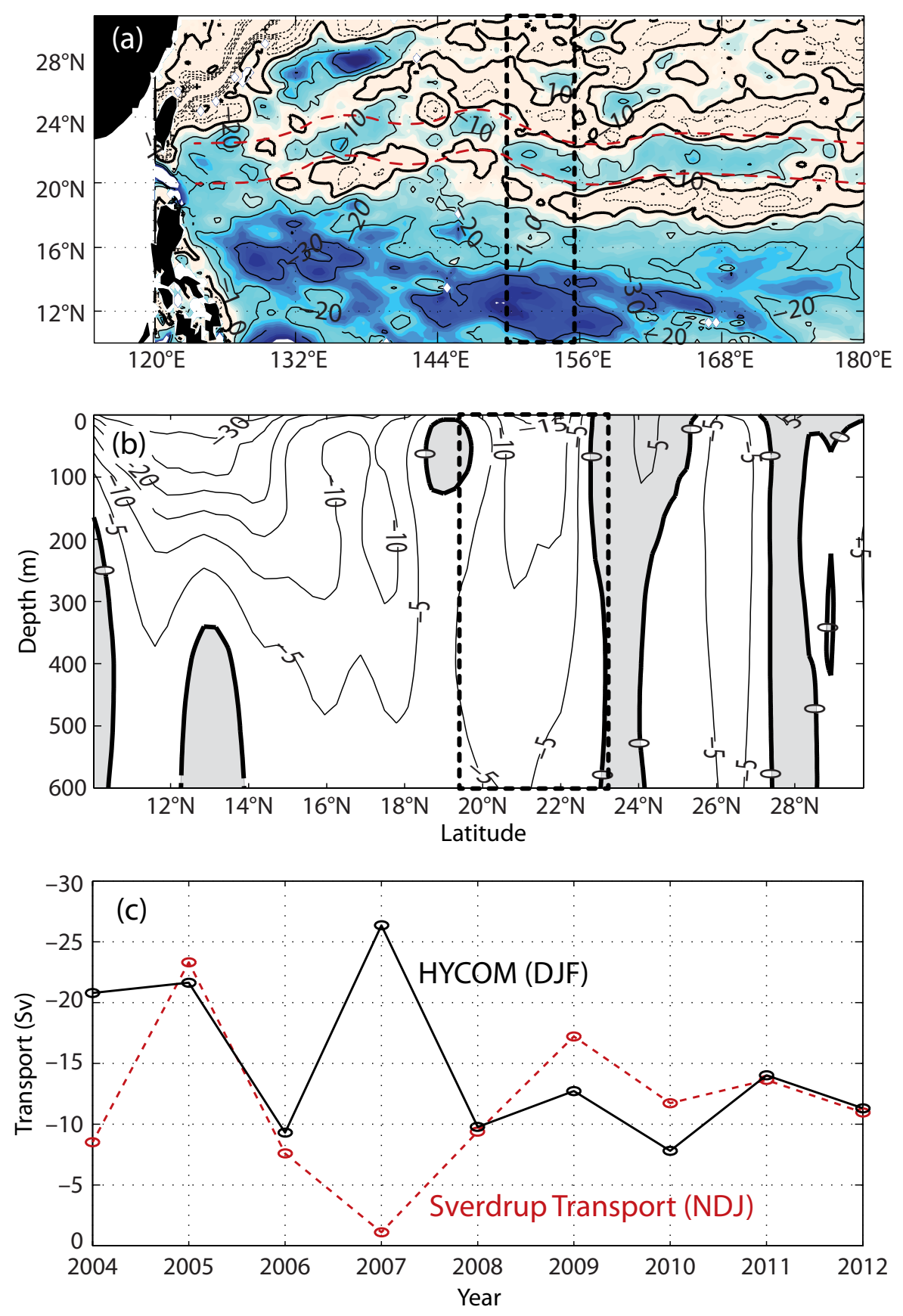

Figure 7. (a) Wintertime zonal velocity (contour interval of $5 \mathrm{~cm} \mathrm{~s}^{-1}$ ) in the Northwest Pacific for 2004/05 from the HYbrid Coordinate Ocean Model (HYCOM). The Wintertime Subtropical Current (WSTC) is highlighted by red dashed lines. The black dashed box denotes the area for the vertical profiles of zonal current in 2004/05 and the zonal transport estimate shown in (c). (b) Vertical profiles of zonal current in the longitudinal band of $150^{\circ}-155^{\circ} \mathrm{E}$ (dashed box in [a]) in 2004/05. (c) Zonal transport of the WSTC Sverdrup transport (red dotted line) from November to January and of HYCOM from December to February in the longitudinal band of $150^{\circ}-155^{\circ} \mathrm{E}$ (dashed box in [a]). 
changes in the circulation pattern of the subtropical North Pacific.

It is proposed here that the winter intensification and the annual variability of the WSTC in the subtropical regions of the North Pacific are reflected in the Kuroshio transport south of Japan in spring, and the lag is the time required for the anomaly to be advected between the two locations. The historical tracks of drogued drifters that crossed $123^{\circ} \mathrm{E}$ between $18^{\circ} \mathrm{N}$ and $23^{\circ} \mathrm{N}$ in winter show that most of them (97\%) join the Kuroshio (Figure 9), thus reinforcing our hypothesis that the WSTC feeds into the Kuroshio. (Only two drifters entered the South China Sea, following the uncommon phenomenon of a strong warm
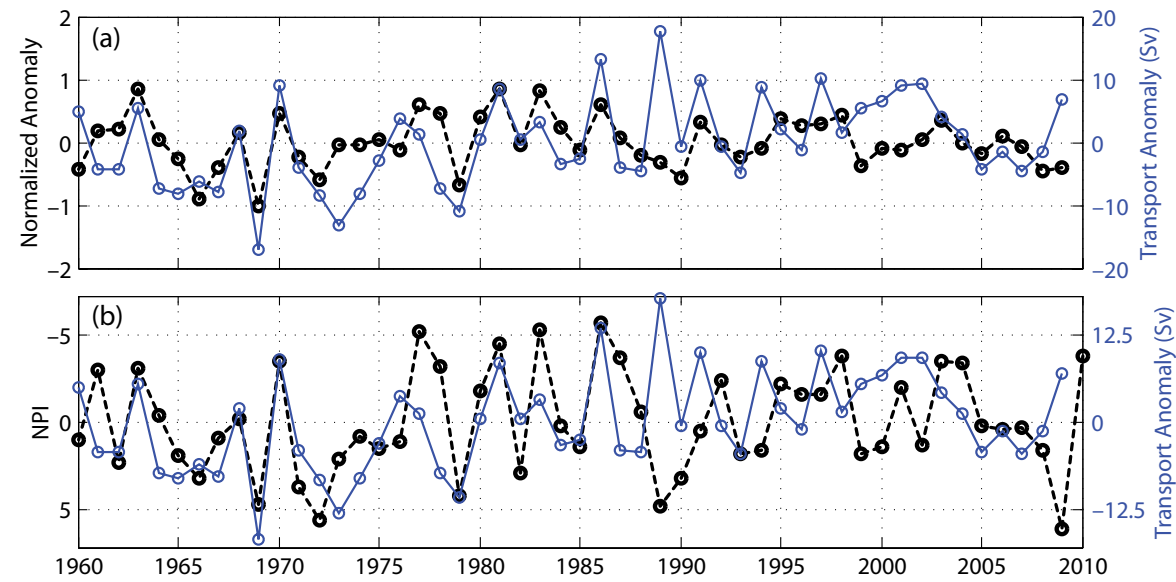

Figure 8. Anomaly of the Wintertime Subtropical Current transport (solid blue line, right axis) and (a) first EOF mode of the winter wind stress curl (dashed black line, left axis) in the North Pacific, and (b) the North Pacific Index (dashed black line, sign reversed left axis). The averaging period for each year is December to February.

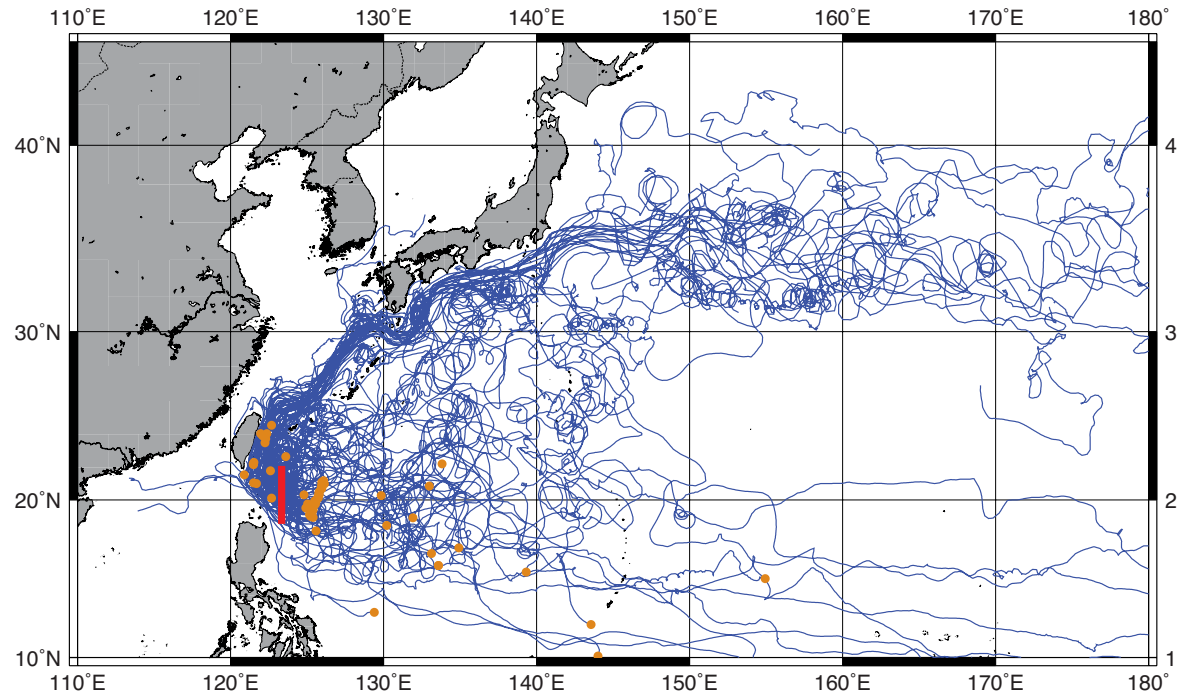

Figure 9. Drifter tracks crossing the $18^{\circ}-23^{\circ} \mathrm{N}$ line (red line) in winter (October to March). Orange circles denote the deployment locations. Note that $20 \%$ of the drifters shown here are deployed west of the red line and cross the red line after recirculating east of Taiwan.

eddy in winter in the area east of Luzon Strait.) Qiu and Joyce (1992) report that the decadal increase in the annual Kuroshio transport from 1970-1980 to 1982-1988 is $10.8 \mathrm{~Sv}$, and Deser et al. (1999) report that the decadal increase in its eastward geostrophic transport between $32^{\circ} \mathrm{N}$ and $37^{\circ} \mathrm{N}$ is $11.5 \mathrm{~Sv}$. The winter Sverdrup transport between $18^{\circ} \mathrm{N}$ and $23^{\circ} \mathrm{N}$ increases by $17 \mathrm{~Sv}$ from 1969-1973 to 1991-1995. Approximately $20 \%$ of drifters that cross the red line in Figure 9 recirculate east of Taiwan, thus offering an alternate explanation regarding why an increase in the Kuroshio transport south of Japan does not reflect all of the WSTC contribution.

The decadal intensification of the westward current toward the western boundary may also cause thermosteric sea level to fall in the narrow zonal band between $18^{\circ} \mathrm{N}$ and $23^{\circ} \mathrm{N}$, which indicates a decrease in the heat content of the upper ocean in that zonal band (Willis et al., 2010). The atmosphereocean coupled model results presented by Sakamoto et al. (2005) show a similar strengthening of the trade winds in the subtropical western Pacific that is consistent with a global warming scenario simulated by a $1 \% \mathrm{CO}_{2}$ increase per year, but it fails to reproduce the observed strengthening of the trade winds and of the wind stress curl in the eastern subtropical Pacific.

The mechanism responsible for the interdecadal variation of the WSTC is the fluctuation of the winter wind stress curl in the North Pacific, which correlates negatively with the strength of the Aleutian Low up to the 1988/89 climate shift. After that time, the governing dynamics of the winter wind stress curl in the subtropical North Pacific changes, 
and we find no significant relationship between the WSTC and the teleconnection patterns or climate indexes in the North Pacific. The WSTC becomes weak and disappears after 2003, but it is expected to have resumed in winter 2010.

\section{ACKNOWLEDGMENTS}

This paper is dedicated to the memory of Peter Niiler-friend, mentor, and colleague of both authors. This work was supported by NOAA grant NA17RJ1231 and ONR grants N00014-10-1-0273, N00014-08-1-0656, and N00014-111-0347. Dong-Kyu Lee was also supported by Pusan National University Research Grant, 2012. Altimeter products were produced by Ssalto/Duacs and distributed by AVISO with support from the Centre National d'Études Spatiale (CNES). 可

\section{REFERENCES}

Balmaseda, M.A., A. Vidard, and D.L. Anderson. 2008. The ECMWF ocean analysis system: ORA-S3. Monthly Weather Review 136:3,018-3,034, http://dx.doi.org/ 10.1175/2008MWR2433.1.

Bentamy, A., and D. Croize Fillon. 2012. Gridded surface wind fields from Metop/ ASCAT measurements. International Journal of Remote Sensing 33(6), http://dx.doi.org/ 10.1080/01431161.2011.600348.

Centurioni, L.R., P.P. Niiler, and D.-K. Lee. 2004. Observations of inflow of Philippine Sea surface water into the South China Sea through the Luzon Strait. Journal of Physical Oceanography 34:113-121, http://dx.doi.org/ 10.1175/1520-0485(2004)034<0113:OOIOPS> 2.0.CO;2.

Centurioni, L.R., P.N. Niiler, and D.-K. Lee. 2009. Near-surface circulation in the South China Sea during the winter monsoon. Geophysical Research Letters 36, L06605, http://dx.doi.org/ 10.1029/2008GL037076.

Chassignet, E.P., H.E. Hurlburt, E.J. Metzger, O.M. Smedstad, J. Cummings, G.R. Halliwell, R. Bleck, R. Baraille, A.J. Wallcraft, C. Lozano, and others. 2009. US GODAE: Global Ocean Prediction with the HYbrid Coordinate Ocean Model (HYCOM). Oceanography 22(2):64-75, http://dx.doi.org/10.5670/oceanog.2009.39.
Deser, C., M.A. Alexander, and M.S. Timlin. 1999. Evidence for a wind-driven intensification of the Kuroshio Current extension from the 1970s to the 1980s. Journal of Climate 12:1,697-1,706, http://dx.doi.org/ 10.1175/1520-0442(1999)012<1697:EFAWDI> 2.0.CO;2.

Gill, A. 1982. Atmosphere-Ocean Dynamics. Academic Press, International Geophysics Series, vol. 30, 662 pp.

Ishi, Y., and K. Hanawa. 2005. Large-scale variabilities of wintertime wind stress curl field in the North Pacific and their relation to atmospheric teleconnection patterns. Geophysical Research Letters 32, L10607, http://dx.doi.org/ 10.1029/2004GL022330.

Johns, W.E., T.N. Lee, D. Zhang, R. Zantopp, C.-T. Liu, and Y. Yang. 2001. The Kuroshio east of Taiwan: Moored transport observations from the WOCE PCM-1 array. Journal of Physical Oceanography 31:1,031-1,053, http://dx.doi.org/10.1175/1520-0485(2001)031 $<1031$ :TKEOTM>2.0.CO;2.

Kakinoki, K., S. Imawaki, H. Uchida, H. Nakamura, K. Ichikawa, S.-I. Umatani, A. Nishina, H. Ichikawa, and M. Wimbush. 2008. Variations of Kuroshio geostrophic transport south of Japan estimated from long-term IES observations. Journal of Oceanography 64:373-384, http://dx.doi.org/10.1007/s10872-008-0030-4.

Kawabe, M. 2005. Variations of the Kuroshio in the southern region of Japan: Conditions for large meander of the Kuroshio. Journal of Oceanography 61:529-537, http://dx.doi.org/ 10.1007/s10872-005-0060-0.

Kobashi, F., H. Mitsudera, and S.-P. Xie. 2006. Three subtropical fronts in the North Pacific: Observational evidence for mode waterinduced subsurface frontogenesis. Journal of Geophysical Research 111, C09033, http:// dx.doi.org/10.1029/2006JC003479.

Lee, D.-K., and P. Niiler. 2010. Influence of warm SST anomalies formed in the eastern Pacific subduction zone on recent El Niño events. Journal of Marine Research 68:459-477, http:// dx.doi.org/10.1357/002224010794657191.

Mantua, N.J., S.R. Hare, Y. Zhang, J.M. Wallace, and R.C. Francis. 1997. A Pacific interdecadal climate oscillation with impacts on salmon production. Bulletin of the American Meteorological Society 78:1,069-1,079, http:// dx.doi.org/10.1175/1520-0477(1997)078 <1069:APICOW>2.0.CO;2.

Maximenko, N., P. Niiler, M.-H. Rio, O. Melnichenko, L. Centurioni, D. Chambers, V. Zlotnicki, and B. Galperin. 2009. Mean dynamic topography of the ocean derived from satellite and drifting buoy data using three different techniques. Journal of Atmospheric and Oceanic Technology 26:1,910-1,919, http:// dx.doi.org/10.1175/2009JTECHO672.1.
Miller, A., D. Cayan, and W. White. 1998. A westward-intensified decadal change in the North Pacific thermocline and gyre-scale circulation. Journal of Climate 11:3,112-3,127, http://dx.doi.org/10.1175/1520-0442(1998)011 <3112:AWIDCI>2.0.CO;2.

Niiler, P.P. 2001. The world ocean surface circulation. Pp. 193-204 in Ocean Circulation and Climate: Observing and Modelling the Global Ocean. G. Siedler, J. Church, and J. Gould, eds, International Geophysics Series, vol. 77, Academic Press.

Qiu, B., and T. Joyce. 1992. Interannual variability in the mid- and low-latitude western North Pacific. Journal of Physical Oceanography 22:1,062-1,079, http://dx.doi.org/ 10.1175/1520-0485(1992)022<1062:IVITMA> 2.0.CO;2.

Rudnick, D.L., S. Jan, L. Centurioni, C.M. Lee, R.-C. Lien, J. Wang, D.-K. Lee, R.-S. Tseng, Y.Y. Kim, and C.-S. Chern. 2011. Seasonal and mesoscale variability of the Kuroshio near its origin. Oceanography 24(4):52-63, http:// dx.doi.org/10.5670/oceanog.2011.94.

Sakamoto, T.T., H. Hasumi, M. Ishii, S. Emori, T. Suzuki, T. Nishimura, and A. Sumi. 2005. Responses of the Kuroshio and the Kuroshio Extension to global warming in a high-resolution climate model. Geophysical Research Letters 32, L14617, http://dx.doi.org/ 10.1029/2005GL023384.

Trenberth, K.E., and J.W. Hurrell. 1994. Decadal atmosphere-ocean variation in the Pacific. Climate Dynamics 9:303-319, http://dx.doi.org/ 10.1007/BF00204745.

Willis, J.K., D.P. Chambers, C.-Y. Kuo, and C.K. Shum. 2010. Global sea level rise: Recent progress and challenges for the decade to come. Oceanography 23(4):26-35, http:// dx.doi.org/10.5670/oceanog.2010.03.

Yasuda, T., and K. Hanawa. 1997. Decadal changes in the mode waters in the midlatitude North Pacific. Journal of Physical Oceanography 27:858-870, http://dx.doi.org/ 10.1175/1520-0485(1997)027<0858:DCITMW> 2.0.CO;2.

Yeh, S.-W., Y.-J. Kang, Y. Noh, and A.J. Miller. 2011. The North Pacific climate transitions of the winters of 1976/77 and 1988/89. Journal of Climate 24:1,170-1,183, http://dx.doi.org/ 10.1175/2010JCLI3325.1. 